\title{
PENERAPAN TALENT MANAJEMENT UNTUK MENINGKATKAN PRODUKTIVITAS KARYAWAN PADA USAHA KECIL DAN MENENGAH (UKM)
}

\author{
IMPLEMENTATION TALENT MANAGEMENT TO IMPROVING OF \\ EMPLOYMENT PRODUCTIVITY AT SMALL MEDIUM ENTERPRISES (SME)
}

\section{Heru Yulianto ${ }^{1)}$, Y. Sutomo ${ }^{2)}$ dan Galuh Aditya ${ }^{3)}$}

1) Program Studi Manajemen Sekolah Tinggi Ilmu Ekonomi Pariwisata Semarang

2) Program Studi Manajemen Institut Teknologi dan Bisnis Semarang

3) Program Studi Manajamen Sekolah Tinggi Ilmu Ekonomi Rajawali Purworejo Alamat Jl. Lamongan Tengah No.2, Bendan Ngisor, Kec. Gajahmungkur, Kota Semarang 50233

Email: hry0007@yahoo.com, galuhaditya.rajawali@gmail.com

\begin{abstract}
ABSTRAK
Sumber Daya Manusia (SDM) yang berkualitas merupakan salah satu faktor penting agar UKM tetap eksis di dunia bisnis yang semakin kompetitif. SDM yang dikelola dengan baik akan meningkat produktivitas kerjanya. Jika produktivitas karyawan maksimal maka tujuan UKM akan tercapai. Upaya yang bisa dilakukan UKM dalam meningkatkan produktivitas karyawan salah satunya adalah menerapkan manajemen bakat. Hasil penelitian berdasarkan tinjauan literatur dan hasil pencarian dokumen online menunjukkan bahwa talent management mengembangkan dan memperkuat karyawan baru pada proses pertama kali masuk UKM (onboarding); manajemen bakat memelihara dan mengembangkan karyawan yang sudah bekerja terlebih dahulu; dan talent managemen dapat menarik sebanyak mungkin karyawan yang memiliki kompetensi, komitmen dan karakter bekerja pada UKM.
\end{abstract}

Kata Kunci: Talent Management, Produktivitas Karyawan,UKM, On Boarding

\begin{abstract}
Quality human resources is a primary factor to existansi of SME in competitive business world. human resources that good managing will be improve of productivity. If employe productivity is maximamum, it is mean that the aim of SME will achiev. The one of effort SME to improve employe productivity is Talent Magement. The result of this research, based of literature and cearch online document show that talent management develop and strong new employ at the process of recruitmen and join with SME (onboarding). Talent management reserve and employe development that had worked, and talent managent can pulled much employe that have competence, commitment and work character in SME.
\end{abstract}

Keyword: Talent Management, productivity, employe, SME, On Boarding

\section{PENDAHULUAN}

Usaha kecil dan menengah (UKM) memiliki peran dalam pengembangan bisnis sebagai kontributor penting bagi ekonomi global dan merupakan penghasil lapangan kerja besar. Studi OECD baru-baru ini menyoroti bahwa lebih dari $99 \%$ perusahaan di negara-negara OECD dan G20 adalah UKM, memberikan kontribusi yang menentukan untuk pertumbuhan (OECD, 2015). Peran strategis yang dimainkan oleh UKM dalam perekonomian dunia dan 


\section{SEGMEN Jurnal Manajemen dan Bisnis \\ Volume 17 No 1 Januari 2021 \\ p-ISSN: 0216-938X e-ISSN: 2684-8414}

penciptaan lapangan kerja bagi UKM

merupakan tema sentral dalam perekonomian agenda sebagian besar pemerintah saat ini (OECD, 2015). UKM memiliki definisi variatif dari satu negara ke negara lain yang ditentukan oleh kriteria kualitatif atau kuantitatif saat membuat perbandingan antar negara tentang jumlah UKM dan jumlah karyawan dalam perusahaan tersebut. Bank Indonesia juga berupaya mewujudkan pertumbuhan ekonomi 7\% di Jateng, dengan terus memacu para pelaku usaha mikro kecil dan menengah (UMKM) Jawa Tengah untuk melakukan ekspor. Hal tersebut lantaran umkm juga merupakan salah satu penggerak perekonomian masyarakat. (Bisnis.com, 2020). Data dari Dinas Perindustrian, Perdagangan, Koperasi dan UMKM diketahui bahwa jumlah pelaku usaha sampai bulan Juni 2019 yang tercatat sekitar 1627 UKM jumlah itu meningkat sekitar 20 persen (Tribun Jateng, 2019).

Sumber Daya Manusia (SDM) yang berkualitas merupakan salah satu faktor penting dalam persaingan bisnis kompetitif saat ini, ketidakpastian dan kompleksitas menuntut Usaha Kecil Menengah (UKM) untuk meningkatkan strateginya agar tetap eksis di dunia bisnis. SDM yang dikelola dengan baik akan menjadi nilai tambah. Daya tarik, motivasi, pengembangan dan retensi karyawan telah lama dikenal sebagai tantangan penting yang dihadapi UKM (Deshpande \& Golhar, 1994; Hornsby \& Kuratko, 1990) dan praktik sumber daya manusia secara keseluruhan diakui sebagai kontributor penting bagi keberhasilan perusahaan UKM (Carlson et al., 2006; Festing et al., 2013; Heneman dkk., 2000; Hornsby \& Kuratko, 1990). Kurniawati dan Yuliando (2015) Faktor terpenting dari kinerja UKM adalah sumber daya manusia. Temuan ini juga mendukung argumen bahwa alasan nonmoneter memainkan peran yang lebih penting daripada alasan finansial. Pengukuran produktivitas seharusnya melibatkan semua individu yang terlibat dalam proses industri itu. Dengan demikian, pengukuran produktivitas bersifat partisipatif. (Wuryaningrum dan Reynanda, 2012). Respatiningsih (2019) Faktor kunci dari permasalahan pengembangan UMKM adalah kurangnya partisipasi karyawan, tujuan yang tidak jelas, evaluasi yang tidak adil, komunikasi yang tidak efektif dan penerapan evaluasi yang tidak efektif. Keberhasilan dalam meningkatkan suatu produktivitas dapat diukur dari perbaikan secara terus-menerus, peningkatan mutu pekerjaan dan pemberdayaan SDM (Siagian, 2002). Menurut Tohardi (2002) faktorfaktor yang mempengaruhi produktivitas tenaga kerja diantaranya adalah pendidikan, keterampilan, disiplin kerja, budaya, etika kerja, manajemen, tingkat penghasilan, kesempatan berprestasi, beban pekerjaan, budaya organisasi dan teknologi. Mengingat pentingnya produktivitas pekerja dalam pencapaian tujuan usaha bisnis, maka diperlukan upaya-upaya perusahaan untuk menunjang meningkatkan produktivitas pekerja.

Peningkatan produktivitas UKM dapat dilakukan dengan menerapkan strategi talent management (Nawangsari dan Sutawijaya, 2018). Manajemen talenta adalah area yang semakin penting dalam berbagai organisasi dan telah muncul sebagai tantangan SDM utama menghadapi perusahaan di berbagai sektor (Farndale et al., 2010; Scullion et al., 2016). Baru-baru ini dikatakan bahwa talent management perlu dipelajari lebih banyak dalam konteks dan lingkungan yang berbeda dan bahwa fokusnya harus diperluas ke pemangku kepentingan yang lebih luas perspektif (Collings, 2014). Selain itu, masih ada kelangkaan penelitian teoritis tentang 


\section{SEGMEN Jurnal Manajemen dan Bisnis \\ Volume 17 No 1 Januari 2021 \\ p-ISSN: 0216-938X e-ISSN: 2684-8414}

HRM dan manajemen bakat di UKM, meskipun semakin diakui pentingnya SDM dan TM dalam konteks UKM (Festing et al., 2013; Valverde et al., 2013). Terlalu sering konsep dan praktik manajemen SDM dan bakat yang dikembangkan di dalam perusahaan besar diterapkan secara tidak kritis dalam UKM (Festing et al., 2013; Heneman et al., 2000) dengan sedikit atau tanpa pengakuan bahwa UKM berbeda dalam beberapa cara-cara mendasar yang berkaitan dengan konteks kelembagaan, sumber daya, dan ekonomi mereka. Oleh karena itu, fokus penelitian ini adalah bagaimana ukuran organisasi yang kecil menciptakan tantangan dan peluang untuk UKM dalam pendekatan talent management pada praktik perekrutan dari kumpulan bakat yang berbeda.

Pemahaman teoritis dari konteks UKM menunjuk ke arah kebutuhan akan cara berpikir baru tentang arti 'bakat manajemen 'dan' bakat 'di UKM, masalah yang akan dieksplorasi lebih lanjut. Mendasarkan argumen kami pada dua tema konseptual didirikan untuk manajemen bakat di perusahaan besar, kami berpendapat bahwa gagasan tentang manajemen bakat tidak dapat ditiru oleh UKM dan bahwa konseptualisasi talent management seperti yang diusulkan untuk perusahaan besar membutuhkan adaptasi dalam konteks UKM. UKM mengalami tingkat yang lebih tinggi ketidakstabilan dalam bentuk struktural dan proses manajemen mereka (Child, 1973; Hanks \& Chandler, 1994; Pugh et al., 1969) di siklus organisasi pendek mereka. Ketika organisasi tumbuh dalam ukuran dan kompleksitas, kami berpendapat bahwa perubahan bentuk struktural membuatnya Lebih sulit bagi UKM untuk secara sistematis mengidentifikasi posisi kunci dan pengembangan kumpulan bakat berpotensi besar untuk mengisi posisi tersebut peran. Selain itu, UKM memiliki tingkat informalitas yang tinggi baik dalam pendekatan umum mereka terhadap HRM dan dalam kaitannya dengan SDM tertentu praktik (Dundon \& Wilkinson, 2009) dan informalitas ini telah diidentifikasi sebagai sumber keunggulan kompetitif bagi UKM (Bacon et al., 1996; Dundon \& Wilkinson, 2009).

Talent Management (TM) telah menjadi salah satu isu strategis utama bagi para pemimpin dalam organisasi global dan mayoritas penelitian tentang talent management berfokus pada perusahaan multinasional besar. Hasil penelusuran penulis diketahui bahwa penelitian konseptual tentang talent management dalam konteksi UKM masih jarang. Penelitian ini mencoba untuk mengatasi kesenjangan ini dengan a) memberikan alasan teoritis untuk penerapan talent management pada UKM; b) mengeksplorasi penerapan gagasan talent management yang dikonseptualisasikan secara luas pada UKM. c) membantu mengidentifikasi karakteristik talent management di UKM. Penelitian ini memiliki pendekatan praktik dan gagasan tentang manajemen bakat cenderung berbeda di UKM dibandingkan dengan perusahaan besar terutama karena ke faktor kelembagaan dan struktural yang berbeda.

\section{TALENT MANAJEMENT}

Definisi talent management atau manajemen bakat adalah proses konstan yang melibatkan, menarik dan mempertahankan karyawan berkualitas tinggi, mengembangkan keterampilan, dan terus memotivasi untuk meningkatkan kinerja. (Khatri, Gupta, Gulati, Chauhan, 2010). Armstrong (2007) manajemen talenta merupakan proses untuk memastikan bahwa organisasi memiliki orang-orang bertalenta yang dibutuhkan untuk mencapai tujuan 


\section{SEGMEN Jurnal Manajemen dan Bisnis \\ Volume 17 No 1 Januari 2021 \\ p-ISSN: 0216-938X e-ISSN: 2684-8414}

bisnisnya. Ini melibatkan manajemen strategis dari aliran bakat melalui organisasi dengan menciptakan dan memelihara saluran bakat. Sedangkan Cheese, et.al (2007) manajemen bakat menjadi bagian dari strategi manajemen sumber daya manusia yang terdiri dari penerapan strategi terintegrasi yang dijalankan untuk meningkatkan dan mempertahankan kinerja organisasi dengan meningkatkan prosedur untuk menarik, mempertahankan, mengembangkan,dan mengambil keuntungan dari individu dengan kualifikasi dan keterampilan yang diperlukan untuk mencapai masa kini dan masa depan persyaratan bisnis.

Hewits Human Capital Insttitute (2008) menemukan bahwa perusahaan dengan praktik bakat yang lebih matang mendorong integrasi dan konsistensi yang lebih baik melalui kombinasi pendekatan, diantaranya: 1) Berinvestasi dalam memberikan solusi teknologi manajemen talenta yang kuat ditambah dengan desain ulang proses; 2) Mendefinisikan lebih jelas peran SDM perusahaan dan lapangan untuk merancang dan memberikan solusi bakat, termasuk penggunaan yang lebih besar dari spesialis bakat (dalam beberapa kasus mitra bisnis) di lapangan untuk membantu meningkatkan integrasi; dan 3) Menerapkan pusat keunggulan global untuk manajemen talenta untuk meningkatkan koordinasi dan konsistensi praktik di seluruh wilayah dan bisnis. Menurut Ashton and Morton (2005), lima kata kunci untuk menjelaskan talent management, yaitu:

1. Etos - menanamkan nilai dan perilaku, yang dikenal sebagai "pola pikir bakat", untuk mendukung pandangan bahwa setiap orang memiliki potensi yang layak untuk dikembangkan.

2. Fokus - mengetahui pekerjaan mana yang membuat perbedaan dan memastikan bahwa orang yang tepat memegang pekerjaan itu pada waktu yang tepat.

3. Positioning - mulai dari bagian atas organisasi dan mengalir ke seluruh tingkat manajemen untuk menjadikannya sebagai inisiatif manajemen, bukan SDM.

4. Struktur - membuat alat, proses, dan teknik dengan akuntabilitas yang ditentukan untuk memastikan bahwa pekerjaan selesai.

5. Sistem - memfasilitasi pendekatan jangka panjang dan holistik untuk menghasilkan perubahan

\section{PRODUKTIVITAS KERJA}

Menurut Sauermann (2016) pengertian produktivitas secara umum didefinisikan sebagai rasio antara ukuran output dan ukuran input. Produktivitas pekerja dapat diukur sebagai output, mis. penjualan atau unit yang diproduksi, relatif terhadap input, mis. jumlah jam kerja atau biaya tenaga kerja. Secara tradisional, produktivitas tenaga kerja diperoleh dari ukuran agregat di tingkat perusahaan, misalnya nilai tambah per pekerja. Beatson dan Zheltoukhova (2015) menyatakan bahwa produktivitas didefinisikan sebagai seberapa efektif nilai (output) dihasilkan dari input (orang, peralatan modal, tanah, energi, dan sebagainya).Menurut Krugman (1994) produktivitas umumnya didefinisikan sebagai rasio antara volume keluaran dan volume masukan. Produktivitas adalah sikap mental yang melatar belakangi karyawan untuk menghasilkan performa kerja lebih baik dari hari kemarin (Hariandja, 2002). Sedang menurut Ravianto et al (1988:14) faktor faktor yang mempengaruhi produktivitas kerja yaitu beberapa faktor yang berhubungan langsung denga tenaga kerja itu sendiri maupun faktor faktor yang lain seperti, pendidikan, pelatihan,

Heru Yulianto, Y. Sutomo dan Galuh Aditya

Penerapan Talent Manajement Untuk Meningkatkan Produktivitas Karyawan Pada Usaha Kecil Dan Menengah (UKM) 


\section{SEGMEN Jurnal Manajemen dan Bisnis \\ Volume 17 No 1 Januari 2021 \\ p-ISSN: 0216-938X e-ISSN: 2684-8414}

keterampilan, kedisiplinan, sikap dan etika kerja,motivasi, gizidan kesehatan, tingkat penghasilan, jaminansosial, lingkungan dan iklim kerja, hubungan industrial,peralatan dan teknologi, kesempatan kerja, dan kesempatan berprestasi. Selain dipengaruhi oleh faktor yang berhubungan dengan tenaga kerja itu sendiri, produktivitas juga dapat dipengeruhi oleh faktor lain seperti keterampilan, gizi dan kesehatan, tingkat penghasilan, jaminan sosial, lingkungan dan iklim kerja, hubungan industri pancasila, teknologi, sarana produksi manajemen, dan kesempatan berprestasi (Rivianto, 1985). Kunci penilaian produktivitas pekerja menurut Sauermann (2016) adalah: Objektivitas: tindakan harus obyektif, berlawanan dengan subjektif, sehubungan dengan supervisor atau penilaian sejawat; 2) Ketersediaan: tindakan perlu untuk tersedia di tingkat individu (pekerja) (yaitu tidak pada tingkat gabungan seperti tingkat tim atau perusahaan); 3) Keterbandingan: tugas dan pengukuran harus sama di antara pekerja dan waktu; 4) Kualitas dan pengendalian: pekerja harus memiliki pengaruh yang cukup pada hasil, yaitu dengan memilih tingkat usaha mereka sendiri.

Berdasarkan beberapa pendapat diatas maka definisi produktivitas pada intinya adalah adalah perbandingan antara jumlah output yang dihasilkan dengan jumlah sumber daya yang digunakan. Dengan kata lain, produkivitas dapat mengukur seberapa efisien input produksi, seperti tenaga kerja dan modal yang digunakan untuk menghasilkan tingkat output tertentu. Sumber utama dari daya saing dan pertumbuhan ekonomi adalah produktivitas. Selain itu produktivitas dapat digunakan sebagai informasi statistik dasar untuk banyak perbandingan internasional dan penilaian kinerja negara. Misalnya, data produktivitas dapat digunakan untuk menyelidiki dampak regulasi produk dan pasar tenaga kerja terhadap kinerja ekonomi.

\section{USAHA KECIL DAN MENENGAH}

Merujuk Undang-undang Nomor 20 Tahun 2008 tentang Usaha Mikro Kecil Dan Menengah memuat kriteria UKM, yaitu sebagai berikut: (a) Usaha Mikro merupakan usaha memiliki kekayaan bersih paling banyak Rp 50.000.000 tidak termasuk tanah dan bangunan tempat usaha; atau memiliki hasil penjualan tahunan paling banyak $\mathrm{Rp}$ 300.000.000; (b) Usaha Kecil merupakan usaha yang memiliki kekayaan bersih lebih dari Rp 50.000.000 sampai dengan paling banyak Rp 500.000.000 tidak termasuktanah dan bangunan tempat usaha; atau memiliki hasil penjualan tahunan lebih dari Rp 300.000.000 sampai dengan paling banyak Rp 2.500.000.000; (c) Usaha Menengah merupakan usaha yang memiliki kekayaan bersih lebih dari Rp 500.000.000 sampai dengan paling banyak Rp 10.000.000.000 tidak termasuk tanah dan bangunan tempat usaha; atau memiliki hasil penjualan tahunan lebih dari Rp 2.500.000.000 sampai dengan paling banyak Rp 50.000.000.000. Definisi khusus mengenai IKM yang dijelaskan oleh BPS adalah sebagai berikut: (a) industri rumah tangga: jumlah tenaga kerja 1-4 orang; (b) industri kecil: jumlah tenaga kerja 5-19 orang; (c) industri sedang atau menengah: jumlah tenaga kerja 20-99 orang; (d) industri besar: jumlah tenaga kerja lebih dari 99 orang.

\section{METODE PENELITIAN}

Penelitian ini menggunakan metode kualitatif deskriptif, dengan pengumpulan data melalui penelusuran dokumen secara online dan literature review. Data yang dikumpulkan berkaitan dengan Implementasi talent management dalam upaya meningkatkan produktivitas karyawan pada Industri Kecil Menengah. Data tersebut 


\section{SEGMEN Jurnal Manajemen dan Bisnis \\ Volume 17 No 1 Januari 2021 \\ p-ISSN: 0216-938X e-ISSN: 2684-8414}

kemudian dianalisis dengan menggunakan beberapa teori tentang Manajement talent dan produktivitas kerja. Hasil informasi yang diperoleh dari proses di atas selanjutnya dianalisa secara deskriptif dan dielaborasi dalam bentuk model yang disesuaikan dengan situasi UKM.

\section{PEMBAHASAN}

UKM mencakup perusahaan dengan berbagai ukuran dengan berbagai tingkat kompleksitas dalam organisasi dan praktik manajemen (Kotey \& Slade, 2005). Karena kebutuhan akan fleksibilitas dalam UKM (Cardon \& Stevens, 2004; Mei 1997) penugasan kerja jarang stabil dan orang perlu bergerak cepat dari satu peran ke peran lainnya. Selain itu, sejumlah besar karyawan menjalankan peran ganda dengan tidak jelas batas-batas dan tanggung jawab pekerjaan (Hanks \& Chandler, 1994; Mei 1997). Menilai kecocokan Orang-Pekerjaan akan sulit dalam skenario seperti itu peran tumpang tindih yang luas tanpa deskripsi pekerjaan formal dan tidak ada penugasan pekerjaan yang stabil. Pada saat yang sama yang penting sebagian besar adalah memiliki kandidat dengan kemampuan dan komitmen khusus perusahaan. "Fase awal yang mengarah ke pembuatan sumber daya, di mana produk pertama dikembangkan dan basis pasar didirikan menuntut upaya besar dan hanya berhasil di tempat ada komitmen bersama "(Garnsey, 1998: 535). Oleh karena itu, dapat dikatakan bahwa UKM sangat memperhatikan yang tidak terkait dengan pekerjaan faktor-faktor seperti kesesuaian dalam norma, nilai, keyakinan pelamar dengan organisasi (Williamson et al., 2002). Ini akan membutuhkan perusahaan untuk menilai kecocokan calon rekrutmen ke perusahaan secara keseluruhan dan tercermin dalam kecocokan Organisasi-Orang (Sekiguchi, 2007).
Saat organisasi menjadi lebih besar, peran tumpang tindih yang luas memberi jalan untuk peran yang lebih terspesialisasi, seiring dengan perkembangan struktur dan mengadopsi bentuk yang lebih fungsional (Blau, 1970). Ukuran organisasi yang lebih besar umumnya dicirikan oleh diferensiasi dan spesialisasi tugas yang lebih tinggi (misalnya Blau, 1970; Child, 1973; Pugh et al., 1969). Perbedaan kompleksitas struktural antara sangat perusahaan kecil dan menengah jauh lebih tinggi daripada perbedaan antara perusahaan menengah dan sangat besar. Ini berarti bahwa ketika sebuah organisasi berkembang dalam ukuran dari sangat kecil menjadi menengah, ada penambahan yang cepat pada pekerjaan khusus, tingkat hierarki dan divisi fungsional menciptakan masalah dalam komunikasi dan koordinasi (Blau, 1970).

Pandangan dinamis tentang manajemen bakat di UKM sangat berbeda dengan konteks manajemen bakat pada perusahaan besar, penting untuk dilakukan mengeksplorasi pertanyaan konseptual utama, seperti siapa yang dianggap 'bakat' di UKM dan apa yang ditekankan dalam pemilihan mereka. Karenanya kami membahas dan berusaha menjelaskan masalah arti bakat dalam konteks UKM. Literatur tentang konteks perusahaan besar menyoroti kurangnya kejelasan istilah ini. Beberapa penulis hampir tidak mendefinisikan apa arti bakat, yang lain mendefinisikannya sebagai objek atau karakteristik orang sementara beberapa orang lain telah mendefinisikannya dalam istilah subjek yang dikategorikan sebagai bakat - semua orang atau beberapa (Gallardo-Gallardo et al., 2013).

Rowden (2002) mengemukakan bahwa keterampilan teknis dan etos kerja dianggap lebih penting dalam proses pemilihan perusahaan manufaktur kecil yang sukses.

Heru Yulianto, Y. Sutomo dan Galuh Aditya

Penerapan Talent Manajement Untuk Meningkatkan Produktivitas Karyawan Pada Usaha Kecil Dan Menengah (UKM) 


\section{SEGMEN Jurnal Manajemen dan Bisnis \\ Volume 17 No 1 Januari 2021 \\ p-ISSN: 0216-938X e-ISSN: 2684-8414}

Studi ini menunjukkan pandangan yang berbeda tentang pentingnya ditempatkan pada Person-Job dan Person-Organization sesuai dengan proses seleksi UKM. Sementara menyesuaikan diri akan menjadi pertimbangan utama pada tahap awal perkembangan, saat perusahaan tumbuh lebih besar, lebih banyak perhatian juga dapat diberikan pada keterampilan dan kemampuan kandidat (Kotey \& Slade, 2005) menyarankan bahwa pada tahapan yang berbeda dalam tahapan kehidupan organisasi berbagai bentuk fit menonjol.

UKM akan terus berubah dalam menanggapi kondisi lingkungan yang dinamis dan manajemen orang yang efektif sangat penting untuk kelangsungan hidup UKM (Jack et al., 2006). Heneman dkk. (2000) mengemukakan bahwa kemampuan karyawan untuk mengembangkan perannya dan pada saat yang sama mengambil peran tingkat yang lebih tinggi seiring pertumbuhan dan perkembangan organisasi merupakan pertimbangan penting untuk berkembang perusahaan kecil. Hal ini menimbulkan pertanyaan dalam kondisi perkembangan perusahaan apa, apakah tipe fit lebih penting. Salah satu cara untuk menguranginya Masalahnya adalah dengan secara formal menentukan siapa yang perlu melakukan apa dalam bentuk deskripsi pekerjaan dan peran pekerjaan formal ini ditemukan untuk ditempatkan secara mantap seiring dengan pertumbuhan organisasi (Kotey \& Slade, 2005; Rutherford et al., 2003).

Lebih lanjut, ketika UKM menjadi lebih besar, persentase karyawan yang multiterampil menjadi lebih sedikit (Kotey \& Slade, 2005). Ini bisa menjadi cerminan tidak hanya dari kemampuan untuk menentukan pekerjaan secara lebih akurat dengan deskripsi pekerjaan formal tetapi juga mencerminkan meningkatnya kebutuhan untuk memiliki spesialis dalam pekerjaan tersebut. Oleh karena itu dapat disarankan bagi UKM kecil, pelamar kerja yang memiliki lebih banyak derajat kecocokan organisasi bisa dipilih karena pelamar tersebut bisa dianggap memiliki bakat, sedangkan ketika UKM mulai tumbuh dalam skala yang lebih besar bisa memilih pelamar kerja yang memiliki tingkat kecocokan pekerjaan-tingkat kecocokan pekerjaan akan menjadi bakat karyawan untuk membantu UKM mengembangkan dan bersaing dalam bisnis.

Berdasarkan kajian literature diatas, maka dapat dijelaskan bahwa Karyawan yang dapat dikategorikan memiliki bakat dapat dilihat dari sikap dan perilakunya, diantaranya adalah:

1. Karyawan yang memiliki bakat memiliki kemampuan untuk membuat dan bisa membantu merumuskan aturan (breaking the rule) yang dipakai untuk meningkatkan kinerja.

2. Karyawan bertalenta dapat dengan mudah beradaptasi dengan perubahan. Karyawan seperti ini dibutuhkan UKM untuk segera menyesuaikan dengan perubahan perilaku konsumen pada bisnis yang semakin kompetitif.

3. Karyawan talenta seringkali menjadi sumber informasi yang dapat dipercaya didalam unit atau organisasinya. Krayawan berbakat akan membantu UKM dalam memberikan data, saran dan kreatif membentuk hal baru serta merubahnya ke arah yang lebih baik.

4. Karyawan bertalenta memiliki kemampuan menciptakan inovasi. Inovasi dibutuhkan UKM untuk memodifikasi produk agar bisa memasuki peluang pasar, cepat menyesuaikan dengan teknologi baru pada proses produksi, mampu 


\section{SEGMEN Jurnal Manajemen dan Bisnis \\ Volume 17 No 1 Januari 2021 \\ p-ISSN: 0216-938X e-ISSN: 2684-8414}

memperbaiki produk secara berkelanjutan dan sebaiknya.

5. Karyawan bertalenta memiliki kemampuan mengarahkan karyawan lain untuk menyelesaikan dan bertanggung jawab dalam pekerjaannya.

6. Karyawan bertalenta memberi inspirasi dan memotivasi karyawan. Karyawan berbakat memiliki kemampuan untuk mendorong orang lain agar segera menyelesaikan pekerjaan sesuai dengan tujuan UKM. Dan memiliki kemampuan untuk mengubah pola pikir kea rah yang lebih positif.

Pertumbuhan UKM dapat diukur melalui peningkatan produktivitas kerja karyawan. Karyawan yang memiliki produktivitas tinggi akan sangat menguntungkan bagi UKM terutama untuk kesejahteraannya. Etos kerja karyawan dapat mencerminkan produktivitas dan sikap mental yang baik. Oleh karena itu, penting bagi pelaku UKM berupaya dengan berbagai kebijakan yang secara efisien agar mampu meningkatkan produktivitas karyawan. Berdasarkan hasil penelusuran dokumen melalui online didapatkan hasil bahwa produktivitas kerja karyawan pada UKM dapat dilihat dari:

1. Kemampuan

Kemampuan seorang karyawan UKM bergantung pada keterampilan yang dimiliki dan profesionalisme karyawan dalam bekerja. Keterampilan dan profesionalisme memberikan daya untuk menyelesaikan setiap tugas yang dibebankan.

2. Meningkatkan hasil yang dicapai

Terdapat upaya dari karyawan untuk meningkatkan hasil produksinya. Karyawan berupaya untuk memanfaatkan produktivitas agar dapat meningkatkan hasil kerja, karena hasil merupakan salah satu hal yang dapat dirasakan oleh yang mengerjakan maupun yang menikmati hasil pekerjaan tersebut diantaranya adalah kebutuhan akan penambahan upah.

3. Semangat kerja

Semangat kerja karyawan dapat diukur dari perubahan hasil kerja yang semakin membaik setiap periodenya.

4. Pengembangan diri

Pengembangan diri dapat dijelaskan melalui indikator keterlibatan karyawan dalam program-program pelatihan atau kursus untuk peningkatan kemampuan karyawan. Karyawan UKM mulai sadar bahwa pelatihan dibutuhkan untuk peningkatan kemampuan diri, sedangkan pemilik UKM menyadari bahwa untuk meningkatkan produktivitas kerja karyawan membutuhkan peningkatan kemampuan.

5. Mutu

Mutu merupakan kualitas kerja yang dihasilkan oleh seorang karyawan. UKM membutuhkan hasil yang baik yang ditunjukkan dengan kualitas kerja karyawan yang nantinya dapat bermanfaat bagi pertumbuhan UKM dan karyawan itu sendiri.

6. Efisiensi

Perbandingan antara hasil yang dicapai dengan keseluruhan sumber daya yang digunakan, masukan dan keluaran merupakan aspek produktivitas yang memberikan pengaruh yang cukup signifikan bagi karyawan

Menerapkan manajemen bakat secara proaktif dapat ditempuh UKM dalam meningkatkan produktivitas karyawan. Penelitian ini menemukan bahwa langkahlangkah yang bisa dilakukan diantaranya adalah:

1. Memilih karyawan yang tepat

Produktivitas karyawan dapat dioptimalkan jika UKM dari awal 


\section{SEGMEN Jurnal Manajemen dan Bisnis \\ Volume 17 No 1 Januari 2021 \\ p-ISSN: 0216-938X e-ISSN: 2684-8414}

menerapkan strategi perekrutan tenaga kerja secara efektif dan efisien. Pemilihan orang-orang yang akan dilibatkan dalam bisnis baiknya dipilih yang berkompeten atau berkualitas. Pemilihan saudara atau tetangga dekat bisa dilakukan jika yang bersangkuta memenuhi kualitas kompetensi yang dibutuhkan. (Respatiningsih, 2019)

Langkah-langkah strategis untuk membuat perekrutan yang lebih cerdas adalah dengan menciptakan peluang dan umpan balik kolaboratif antara kandidat dengan UKM. Jika tidak terdapat orangorang pilihan di sekitar lingkungan usaha maka. Langkah Cerdas dan bijak harus berani dilakukan oleh Pemilik UMKM agar jajaran manajemen berisi orangorang yang berkualitas.

UKM dapat menginformasikan secara jelas kebutuhan kompetensi dan kompensasi yang akan diberikan. Informasi perekrutan secara efektif dan efisien dapat langsung ditujukan melalui penyedia tenaga kerja sesuai spesifikasi yang dibutuhkan misalnya mengoptimalkan tracer study dan pusat karier dari perguruan tinggi, informasi ke lembaga/kursus yang menghasilkan tenaga kerja kompeten dan sebagainya.

2. Sederhanakan Proses Orientasi

Keberhasilan karyawan baru sebagian besar bergantung pada proses orientasi. Faktanya, organisasi yang menawarkan program orientasi mengalami peningkatan produktivitas 54 persen dari karyawan baru (Aberdeen Group). Orientasi yang efektif juga mencakup menetapkan tujuan untuk karyawan baru dan menjelaskan bagaimana tujuan ini terkait dengan misi organisasi, sehingga karyawan memahami nilai yang mereka bawa ke organisasi sejak hari pertama karyawan bekerja.
3. Meningkatkan keterlibatan karyawan Peningkatan produktivitas karyawan akan terus meningkat jika UKM terus melibatkan karyawan dalam membuat keputusan UKM. Karyawan yang diikutkan pelatihan pemasaran secara rutin akan menghasilkan penjualan dan laba kotor yang lebih tinggi. Artinya bakat karyawan akan terlihat jika dilibatkan dalam pengambilan keputusan UKM khususnya dalam mengambil keputusan pada bidang pekerjaannya. Selain itu keterlibatan karyawan bisa dilakukan dengan cara melakukan umpan balik dan meninjau kembali pekerjaan karyawan secara konsisten

4. Pertahankan karyawan yang memiliki kinerja kuat

UKM harus memahami bahwa tingkat retensi karyawan tidak hanya bergantung pada pelatihan dan pengembangan karyawan, akan tetapi UKM harus memelihara karyawan yang memeiliki bakat dengan baik. Identifikasi karyawan berpotensi tinggi, dan tawarkan mereka kesempatan untuk tumbuh dan menguji keterampilan untuk peran masa depan.

5. Kompensasi yang sesuai

Pemberian kompensasi yang sesaui akan membantu mempertahankan karyawan yang berbakat untuk bisa konsisten meningkatkan produktivitasnya. Hal ini berarti UKM harus memperhatikan kompensasi yang seimbang dengan produktivitas yang sudah diberikan. Kompensasi bagi karyawan berbakat yang berkinerja tinggi adalah hal wajib yang harus diperhatikan oleh UKM, karean karyawan berkinerja tinggi adalah kunci kesuksesan bisnis UKM.

6. Mengidentifikasi dan mengatasi karyawan yang akan dipertahankan atau dilepas

Heru Yulianto, Y. Sutomo dan Galuh Aditya

Penerapan Talent Manajement Untuk Meningkatkan Produktivitas Karyawan Pada Usaha Kecil Dan Menengah (UKM) 


\section{SEGMEN Jurnal Manajemen dan Bisnis \\ Volume 17 No 1 Januari 2021 \\ p-ISSN: 0216-938X e-ISSN: 2684-8414}

Manajemen bakat termasuk disini adalah upaya mengidentifikasi karyawan yang tidak produktif dan membutuhkan bimbingan. Ukuran tidak produktif ditandai dengan kemalasan dan tidak tercapainya standar pekerjaan. Sedangkan karyawan yang membutuhkan bimbingan bukan berarti malas, hanya saja membutuhkan lebih banyak pelatihan dan bimbingan. Identifikasi ini akan membantu UKM untuk memutuskan apakah karyawan akan dipertahankan atau justru dilepas. Evaluasi kinerja yang jelas memudahkan untuk menentukan penyebab pasti dari pelepasan karyawan, apakah itu kebutuhan untuk lebih banyak pelatihan, arahan pekerjaan yang lebih baik atau tinjauan yang serius.

\section{PENUTUP}

Implementasi talent management ditentukan oleh karakteristik tenaga kerja. Mengelola talenta karyawan merupakan tuntutan dalam konteksi UKM. Persyaratan utama untuk talent management yang efektif di UKM adalah persyaratan yang harus dikaitkan dengan prioritas strategis UKM. Ini bisa berdampak pada penekanan yang ditempatkan pada seleksi di UKM dan bisa menentukan pengertian bakat. Dibutuhkan pemahaman bakat pada pengelolaan manajemen UKM terutama pada saat pemilihan karyawan. Seperti yang dikemukakan sebelumnya, memilih karyawan yang memiliki bakat akan menambah nilai terbaik bagi UKM. Oleh karena memeriksa proses keputusan seleksi merupakan faktor penting yang menentukan karakteristik bakat dalam konteks UKM. Strategi perekrutan dan perekrutan yang cerdas, program pelatihan yang hebat, dan metode untuk membina pekerja yang berkinerja terbaik maupun pekerja lepas, akan dapat meningkatkan produktivitas karyawan untuk pengembangan UKM.
Artinya penerapaan manajemen bakat dapat meningkatkan produktivitas karyawan pada Usaha Kecil dan Menengah.

Kontribusi utama penelitian ini adalah pertama memberikan pemahaman teoritis tentang penerapan manajemen bakat untuk meningkatkan produktivitas UKM. Kedua, penelitian memperluas pekerjaan konseptual pada TM ke konteks UKM dan menjelaskan faktor-faktor utama yang mempengaruhi keputusan TM dalam meningkatkan produktivitas UKM, dan Ketiga, memahami TM akan mengingat bahwa kualitas karyawan menjadi faktor penting dalam upaya mengembangkan UKM. Penelitian ini membantu menjembatani kesenjangan dalam literatur dengan mengidentifikasi sifat yang berubah manajemen bakat selama evolusi UKM. Penelitian masa depan dapat mencoba untuk lebih meningkatkan pemahaman kita tentang dinamika sifat hubungan antara konteks organisasi dan manajemen bakat, mempertimbangkan pentingnya elemen kontekstual seperti lingkungan yang lebih spesifik, strategi UKM dan asal usul bakat dalam menentukan pengertian bakat dan talent management di UKM. Ini memperdalam pemahaman kita mengapa dan bagaimana talent management berbeda dalam berbagai konteks UKM.

\section{DAFTAR PUSTAKA}

Al-manaf, rival. https://jateng.tribunnews.com/2019/08/ 04/produksi-usaha-mikro-dan-kecil-dijateng-semakin-tumbuh-pemerintahsiapkan-inkubator.

Armstrong, M., Armstrong's handbook of human resource management practice, 2012, 12th edition, Kogan Page, pp255269

Bacon, N., Ackers, P., Storey, J., \& Coates (1996). It's a small world: Managing 


\section{SEGMEN Jurnal Manajemen dan Bisnis \\ Volume 17 No 1 Januari 2021 \\ p-ISSN: 0216-938X e-ISSN: 2684-8414}

human resources in small business.

International Journal of Human

Resource Management, 7(1), 82-100.

Beatson, Mark and Ksenia Zheltoukhova. 2015. Productivity: Getting the best out of people. CIPD Policy Report. July 2015. P.10

Blau, P. M. (1970). A formal theory of differentiation in organizations. American Sociological Review, 35, 201-218.

Cardon, M. S., \& Stevens, C. E. (2004). Managing human resources in small organizations: What do we know? Human Resource Management Review, 14(3), 295-323.

Carlson, D. S., Upton, N., \& Seaman, S. (2006). The impact of human resource practices and compensation design on performance: An analysis of familyowned SMEs. Journal of Small Business Management, 44(4), 531-543.

Cheese, P.; Thomas, R.J.; Craig, E. 20017. The Talent Powered Organization: Strategies for Globalization, Talent Management and High Performance; Kogan Page: New York, NY, USA. 421

Child, J. (1973). Predicting and understanding organization structure. Administrative Science Quarterly, 18, 163-177.

Collings, D. G. (2014). Toward mature talent management: Beyond shareholder value. Human Resource Development Quarterly, 25(3), 301-319.

Deshpande, S. P., \& Golhar, D. Y. (1994). HRM practices in large and small manufacturing firms: A comparative study. Journal of Small Business Management, 32(2), 49-56.
Dundon, T., Wilkinson, A., \& Collings, D. (2009). Human resource management in small and medium sized enterprises. In G. Woods (Ed.), Human resource management: A critical introduction. London: Routledge.

Endratno, Hermin. Talent Management Dalam Meningkatkan Kinerja Organisasi.

https://core.ac.uk/download/pdf/26794 7775.pdf

Farndale, E., Scullion, H., \& Sparrow, P. (2010). The role of the corporate HR function in global talent management. Journal of World Business, 45(2), 161168.

Fitriyanto, N. 2012. Pengaruh Motivasi Kerja, Disiplin Kerja dan Pengalaman Kerja Terhadap Produktivitas Kerja Karyawan Pada Industri Kerajinan Topeng Di Dusun Bobung Putat Patuk Kabupaten Gunungkidul. Skripsi. Universitas Negeri Yogyakarta.

Festing, M. (2007). Globalisation of SMEs and implications for international human resource management research and practice. International Journal of Globalisation and Small Business, 2(1), 5-18.

Festing, M., Schäfer, L., \& Scullion, H. (2013). Talent management in mediumsized German companies - An explorative study and agenda for future research. The International Journal of Human Resource Management, 24(9), 1872-1893.

Gallardo-Gallardo, E., Dries, N., \& González-Cruz, T. F. (2013). What is the meaning of 'talent' in the world of work? Human Resource Management Review, 23(4), 290-300. 


\section{SEGMEN Jurnal Manajemen dan Bisnis \\ Volume 17 No 1 Januari 2021 \\ p-ISSN: 0216-938X e-ISSN: 2684-8414}

Garnsey, E. (1998). A theory of the early growth of the firm. Industrial and Corporate Change, 7(3), 523-556.

Hanks, S. H., \& Chandler, G. N. (1994). Patterns of functional specialization in emerging high-tech firms. Journal of Small Business Management, 32, 23.

Heneman, R. L., Tansky, J. W., \& Camp, S. (2000). Human resource management practices in small and medium-sized enterprises: Unanswered questions and future research perspectives. Entrepreneurship: Theory and Practice, 25(1), 11.

Hornsby, J. S., \& Kuratko, D. F. (1990). Human resourcemanagement in small business: Critical issues for the 1990s. Journal of Small Business Management, 28(3), 9-18.

Jack, S., Hyman, J., \& Osborne, F. (2006). Small entrepreneurial ventures culture, change and the impact on HRM: A critical review. Human Resource Management Review, 16(4), 456-466.

Khatri, Preeti, et.al. 2010. Talent Management in HR. Journal of Management and Strategy. 1, No. 1; December 2010. ISSN 1923-3965, EISSN 1923-3973, 39-46

Kotey, B., \& Slade, P. (2005). Formal human resource management practices in small growing firms. Journal of Small Business Management, 43(1), 16-40.

Krugman, Paul. 1994. Defining And Measuring Productivity. The Age of Diminishing Expectations. https://www.oecd.org/sdd/productivitystats/40526851.pdf.

Kurniawati, Dewi. Hendri Yuliando. 2015. Productivity Improvement of Small Scale Medium Enterprises (SMEs) on
Food Products: Case at Yogyakarta Province, Indonesia. Agriculture and Agricultural Science Procedia 3. December 2015, 189 - 194

OECD (2015). Taxation of SMEs in OECD and $G 20$ countries. OECD tax policy studies no. 23 Paris.

Pugh, D. S., Hickson, D. J., Hinings, C. R., \& Turner, C. (1969). The context of organization structures. Administrative Science Quarterly, 91-114

Revianto.J. 2006. Produktivitas dan Tenaga Kerja Indonesia. Jakarta: Lembaga

Sarana Informasi Usaha dan Produktivitas.

Rizqi, Alif Nazzala - Bisnis.com 25 Februari 2020. Kejar Pertumbuhan Ekonomi 7 Persen, UMKM Jateng Didorong Garap Ekspor. https://semarang.bisnis.com/read/20200 225/536/1205781/kejar-pertumbuhanekonomi-7-persen-umkm-jatengdidorong-garap-ekspor.

Respatiningsih, Hesti. 2019. Manajemen Kinerja Usaha Mikro kecil dan Menengah. Segmen: Jurnal Manajemen dan Bisnis. Volume 15, No 2, Juli 2019, p-ISSN: 0216-938X e-ISSN: 26848414. 48-65

Rowden, R. W. (2002). High performance and human resource characteristics of successful small manufacturing and processing companies. Leadership and Organization Development Journal, 23(2), 79-83.

Rutherford, M.W., Buller, P. F., \& Mcmullen, P. R. (2003). Human resource management problems over the life cycle of small to medium-sized firms. Human Resource Management, 42, 321-335 


\section{SEGMEN Jurnal Manajemen dan Bisnis \\ Volume 17 No 1 Januari 2021 \\ p-ISSN: 0216-938X e-ISSN: 2684-8414}

Sauermann, Jan. 2016. Performance Measures And Worker Productivity. Choosing the right performance measures can inform and improve decision-making in policy and management. Performance measures and worker productivity. IZA World of Labor 2016: 260doi: 10.15185/izawol.260 |Jan Sauermann (C) |May 2016|wol.iza.org. 3-4

Sekiguchi, T., \& Huber, V. L. (2011). The use of person-organization fit and person-job fit information inmaking selection decisions. Organizational Behavior and Human Decision Processes, 116(2), 203-216.

Sulaeman, Ardika. 2014. Pengaruh Upah dan Pengalaman Kerja terhadap Produktivitas Karyawan Kerajinan Ukiran Kabupaten Subang. Jurnal Ekonomi. Trikonomika. ISSN 1411514X. Volume 13, Nomor 1, Juni 2014

Tohardi, (2002), Pemahaman Praktis Manajemen Sumber Daya Manusia,. Universitas Tanjung Pura.
Undang-undang Nomor 20 Tahun 2008 Tentang Usaha Mikro, Kecil, dan Menengah

Valverde, M., Scullion, H., \& Ryan, G. (2013). Talent management in Spanish medium sized organizations. International Journal of Human Resource Management, 24(9), 18321852.

Williamson, I. O., Cable, D.M., \& Aldrich, H. E. (2002). Smaller but not necessarily weaker: howsmall businesses can overcome barriers to recruitment. In J. Katz, \& T.M. Welbourne (Eds.), Managing people in entrepreneurial organizations: Learning from the merger of entrepreneurship and human resource management (pp. 83-106). Amsterdam: Jai Press.

Wurjaningrum, Febriana. Reynanda A.R.2012. Pengaruh Perbaikan Kualitas Terhadap Kinerja Operasi Ukm Garmen Surabaya Dengan Perbaikan Produktivitas Sebagai Variabel Intervening. Buletin Studi Ekonomi,Volume 17, No. 2, Agustus 2012. ISSN 1410-4628 
SEGMEN Jurnal Manajemen dan Bisnis

Volume 17 No 1 Januari 2021

p-ISSN: 0216-938X e-ISSN: 2684-8414

Heru Yulianto, Y. Sutomo dan Galuh Aditya

Penerapan Talent Manajement Untuk Meningkatkan Produktivitas Karyawan Pada Usaha Kecil Dan Menengah (UKM) 